DE DE GRUYTER

OPEN

DOI: 10.1515/jolace-2016-0026

\title{
A critical look at the portfolio as a tool for teacher cognition at pre-gradual level: perceptions of students
}

\author{
Zuzana Straková, University of Presov, Slovakia \\ zuzana.strakova@unipo.sk
}

\begin{abstract}
Trainees in teacher training programmes experience a variety of courses focusing on helping them to master the basic skills as future language teachers. The most important issue in the entire training is the appropriate balance between the input they receive from the trainer and the hands-on experience in which they learn through experience. One of the best hands-on activities during teacher training is indisputably teaching practice, i.e. real experience of trainees in the school context. Teaching practice offers to trainees first experience with teaching English lessons with holding responsibility for planning, carrying out the lessons as well as learning from this experience, maintaining a good rapport with students and many other aspects. Since trainees work in the external setting without the presence of their Methodology course trainers, it is often a custom to ask trainees to keep a portfolio with lesson plans or material they used during teaching as well as some reflections on the first teaching experience, so that the trainers could create a picture of how their trainees succeeded "out there". Such a portfolio serves as a useful tool not only for the trainee since the portfolio offers a record of how they managed to carry out specific duty at a specific time; portfolio of this type can provide the trainer with a plastic picture of how trainee managed to apply what they had learned in their Methodology courses. There are many elements which can be included in the teaching practice portfolio such as less on plans, reflections, various case studies, textbook evaluations, sample teaching aids prepared by the trainee, etc. However, the biggest benefit that portfolio provides the trainee with is the reflection itself - thinking about how successfully something has been mastered and thinking about how things could be done better. EPOSTL (European Portfolio for Student Teachers of Languages) where trainees focus on self-evaluation of their own teaching skills is one of the tools that can help to focus the trainee on specific skill the teacher needs to master. This article tries to answer the question whether trainees are aware of the beneficial effects of such reflection, whether they perceive a tool like the EPOSTL as something that can help them to develop or they consider it rather a duty to be carried out as a part of training. Based on the experience with a group of trainees who used EPOSTL during their teaching practice this case study analyses possible strengths and weaknesses of including such a complex material as EPOSTL in pre-service teacher training.
\end{abstract}

Key words: reflection, teacher cognition, portfolio, reflective teacher training, foreign language teachers, EPOSTL 


\section{Introduction}

Reflective practice is acknowledged by many professions to be an important tool for growth and development (Marzano, 2012, p.4). In teacher education, it seems to be a legitimate part of many teacher training programmes even though the exact way how it is incorporated into individual programmes would differ in the same way as experts differ in the way they define what reflective practice exactly means (Walsh, Mann, 2015).

Reflection as it was presented in the work of Dewey (1933) offers the space for discovery, argumentation, belief-disclosure, internalisation of principles based on experience through the entire course of teacher education. It involves examination of personal "teaching experience as a basis for evaluation and decision making and as a source for change" (Richards, Lockhart, 1994, p.4) and it can be conducted by many tools such as diaries or journals, questionnaires or checklists, collection of sample trainee's products, lesson reports, focused feedback logs etc. in a written form (whether paper-and-pen or digital e-versions e.g. Cimermanová, 2015) or it may take an oral form in e.g. feedback sessions with a tutor/peers/supervisors, discussions, etc.

The need for teacher education which incorporates constructivist views, reflective practices and evidence-based training is advocated by many educationalists (e.g. Richards, Lockhart, 1994, Spilková, 2007, Gough, 2007, Pollard et.al, 2008). Reflection, however, can fulfil its function only when it is applied in a systematic way, in a cyclical and spiralling process (Pollard et al., 2008) which implies that reflection must be carried out on a regular base. Reflection as a process connected to critical thinking, consideration and reconsideration of an act or experience is the way to use a snapshot from the memory to retrieve the details connected to it. During the act itself it is hardly possible to be aware of all incidents, causes and consequences, alternative ways of solving problems, etc. Looking back at the act on our own or as the outcome of a guided process can open the channels for learning from this experience.

However, reflection should not be based on incidental retrievals of flashbacks, something that Gün (2011, p.126) calls reacting rather than reflecting, but its benefits can be maximised only by a systematic approach stemming from tangible data rather than a vague feeling. Furthermore, the data needs to be used for clarification of intentions, thorough argumentation, and genuine search for best alternatives. Walsh and Mann (2015) support the idea that reflective practice in this or that way should be based on some data, some evidence; moreover, the process of reflection is according to them often wrongly seen as purely individual process while the place collaboration is underestimated (ibid., p.352).

Trainees in teacher training programmes are usually expected by the course tutor to carry out reflection during the course to enhance the quality and personalisation of the learning process. Some tasks might be based on 
collaboration while the other tasks can focus on more individualised outcomes. One such task can be the use of self-assessment portfolio through which the trainee can practise the reflection process which is focused and based on evidence.

\section{Portfolio in pre-service education}

Portfolio in general serves as a collection of documents (MacBeath, J. et al., 2000), outcomes or products of the author over a period. It has been widely used in educational context from early years of schooling (Belásová, Bernátová, 2007) up to the tertiary level since it can document the learner's progress and achievements.

In teacher education portfolio - as a tool for reflection and at the same time for development of a teacher - has been used in many contexts in various pre-service as well as in-service programmes. In pre-service teacher training the portfolio is often connected to the initial teaching practice although it can be used as a part of the Methodology course as well. It often serves as a collection of documents connected to teaching practice such as lesson plans, feedback reports, essays, evaluations, etc. Píšová (2007) collected the experience of using the portfolio in teacher training programmes from the Czech Republic (e.g. Spilková, Svatoš, Holý, Brebera, Černá, Kostková, Dvořáková, Janda, Štáva, Mazáčová, Kratochvílová, Vojtková, Marková) and Slovakia (Doušková, Belásová, Bernátová). The research outcomes presented in these studies advocate the relevance of using portfolio in pre-service teacher training as a legitimate tool for reflection. The experience varies from using the portfolio in the process of teacher development as an evidence-based tool (e.g. Svatoš, Holý, op.cit.) where trainees can monitor their own progress in using portfolio for evaluative purposes e.g. in the final graduation exams (Spilková, op.cit.).

Self-evaluative function of the portfolio provides opportunities for trainees to exercise their skills of setting realistic goals and thus direct their own learning (Bullock, 2011) especially if they are offered some criteria according to which they can measure up.

\subsection{European Portfolio of Student Teachers for Languages (EPOSTL)}

EPOSTL has been designed by European Centre for Modern Languages as a document serving for the development of reflective skills of trainees in teacher training programmes. The authors (Newby et al, 2007) aimed at supporting the process of development of trainees' reflection in such areas which are usually covered by the Methodology syllabi and are important for future teachers of foreign languages. The aims stated explicitly for the trainee in the document are as follows:

- to encourage you to reflect on the competences a teacher strives to attain and on the underlying knowledge which feeds these competences; 
- to help prepare you for your future profession in a variety of teaching contexts;

- to promote discussion between you and your peers and between you and your teacher educators and mentors;

- to facilitate self-assessment of your developing competence;

- to provide an instrument which helps chart progress. (ibid., p.5).

This document is divided into several sections and within each section trainees have a set of several descriptors focusing on key skills the future teacher should be able to demonstrate. Trainees are offered a bar for each descriptor and they decide how strong they feel within each area. They are invited to use the portfolio in various parts of their development and colour the bars in such a way that it becomes clear how much progress they have made.

There are nearly 200 descriptors so the portfolio is an extensive document. Besides the part of self-assessment there are two other parts in this portfolio - the personal statement and the dossier. The personal statement section focuses the attention of the trainee on the basic questions connected to teaching in general while the dossier is a collection of such documents or learning outcomes which can serve as the evidence of the developmental process.

EPOSTL became the prime focus of this study in which trainees using this document during their teaching practice expressed their attitudes towards the portfolio as a learning tool for the future teachers.

\section{The Study: Attitudes towards the use of EPOSTL}

Based on experience with EPOSTL (Straková, 2010, 2015) a focused study was conducted with the aim to:

- to identify trainees' attitudes towards using a reflective developmental tool;

- to disclose trainees' beliefs about possibility to develop through reflection;

- to identify the level of autonomy of the trainees in handling the reflective process;

- to find out how practicality of EPOSTL is viewed by the trainees;

- to specify the possible benefits from using this tool in the future.

The study was conducted with a group of trainees $(n=36)$ in a two-year teacher training programme. The trainees were in the second semester of the ELT Methodology course and they have accomplished two types of teaching practice one-week observation practice and a two-week teaching practice. One-week observation practice is based on the observations trainees conduct during the period of one week. These observations are not connected to the area of study of a trainee, i.e. they do not observe only English lessons. The reason for this is to focus their attention to the teaching process in general, observe teachers, classroom communication, classroom management, etc. Two-week teaching practice is based on certain number of lessons (16) trainees must teach within the area of their 
subject. The teaching experience is analysed afterwards with their supervising teachers. The first teaching practice is conducted at elementary schools while the second teaching practice is based on secondary schools. Trainees involved in the study have had the prior experience with EPOSTL and provided the feedback on the EPOSTL after the return from the second teaching practice.

The study was conducted via questionnaires with 25 closed questions and it used the response scale for all items of Likert rating scale coded as follows:

Strongly (StD)/ Moderately (MD)/ Slightly (SID) Disagree - Neutral (N) Slightly (SIA) / Moderately (MA)/Strongly (StA) Agree. This type of response scale provided trainees with an option to consider their response within a wider variety of options.

Five areas in the questionnaire indicated the main interest areas connected to the EPOSTL as a developmental tool for pre-service teacher training:

- Responsibility: questions within this area should reveal the responsibility level of trainees which included fulfilling the task - i.e. indicating the development on the individual bars -, informing the supervisor about EPOSTL, checking the descriptors before TP, interest in how other trainees scored as well as the overall feeling of being responsible for the tool, etc.

- Autonomy: because students needed to handle the entire evaluation process on their own, they were expected to demonstrate certain level of autonomy since they needed to decide how and when to work with EPOSTL, they were coping with the power of decision-making - evaluation of progress and indication of space for improvement

- Development: the use of EPOSTL could help the students to gain confidence, to become aware of what they can do (strengths and weaknesses) as well as of the complexity of teacher's job

- Beliefs: beliefs seem to be the most important guide in the decision-making process; this set of questions was focused on their beliefs connected to the importance of reflection, guidance, thinking, or security for the teacher

- Practicality: a very important factor in using any tool for development is how practical or user-friendly this tool is; the factors as usefulness, time, convenience, e-version or paper-and-pen version, comprehensibility, etc. can influence whether the teacher or the teacher-to-be will be happy to work with the tool or just use it because the course tutor requires it.

Trainees filled in the questionnaires after they returned from the teaching practice and there was a group-discussion held after the data were analysed to create space for clarification. Since one of the aims was to become clear whether trainees see the use of EPOSTL as beneficial the discussion was oriented on justification of attitudes within selected areas. 


\section{Discussion of findings}

As to responsibility-related findings (fig.1) trainees in an overt question confirmed they felt responsible for their own progress (with the distribution StA $16,6 \%$, MA $22,2 \%$, SIA 36,1\%). However, it was clear that trainees felt more responsible towards their methodology tutors since they tried to fill in nearly all descriptors even though they were of such nature that was impossible to experience within a short teaching practice. For instance, the descriptors connected to extracurricular activities such as school trips, excursions (e.g. "I can help to organise exchanges in cooperation with relevant resource persons and institutions," or "I can evaluate the learning outcomes of school trips, exchanges and international cooperation programmes.") the trainees expressed relatively high level of agreement based on no experience.

Figure1: Category 1: Responsibility

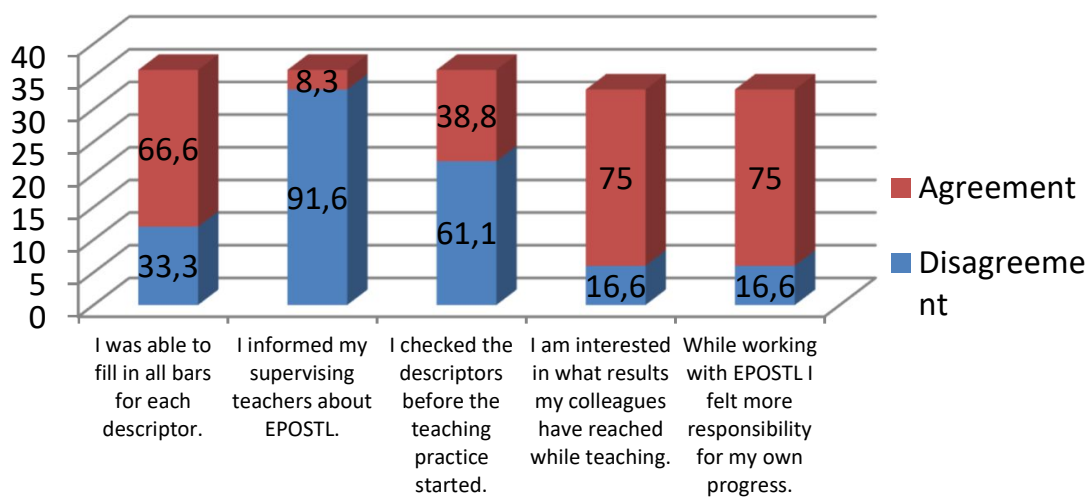

When addressed later with what evidence they could provide they confessed they had only anticipated they could do it but they felt the pressure of the document to state some answer. It seems that trainees need to be instructed very clearly that it is expected they have evidence to support their self-evaluation. Although it needs to be admitted while repertoire of the EPOSTL descriptors is too broad which can mislead trainees in understanding that this kind of skill is required from them from the very beginning. Student teachers within their initial teaching practice do not usually experience a lot of extracurricular activities. Another interesting finding was the fact that trainees did not feel the urge to reveal the use of such a developmental tool as EPOSTL to their supervising teachers. They did not consider EPOSTL as a useful document for their supervisors to know 
although it could have generated a nice discussion about the complexity of a teacher's job with a practitioner. Supervisors could have provided trainees with their viewpoints and trainees thus missed a chance to consider both sides of the same coin.

Similar weakness in responsibility can be seen in their attitude towards checking EPOSTL descriptors before the teaching practice started since it can signal they did not consider this document of lesser importance in connection to their teaching. More than 60\% trainees (with the distribution StD 47,2\%, MD $11,1 \%, 2,8 \%$ SID) ignored EPOSTL before teaching practice and only looked at the descriptors when it was over.

The category of autonomy (fig.2) was oriented towards the decision-making process, self-evaluation as well as the category of power. It is interesting to notice that even though the inclination towards the autonomous handling of the learning process prevailed the trainees expressed rather faint attitudes, especially in the "power" area (only 55,5\%A) they do not prefer to at least share the control of their own learning.

Figure 2: Category 2: Autonomy

Agreement

Disagreement

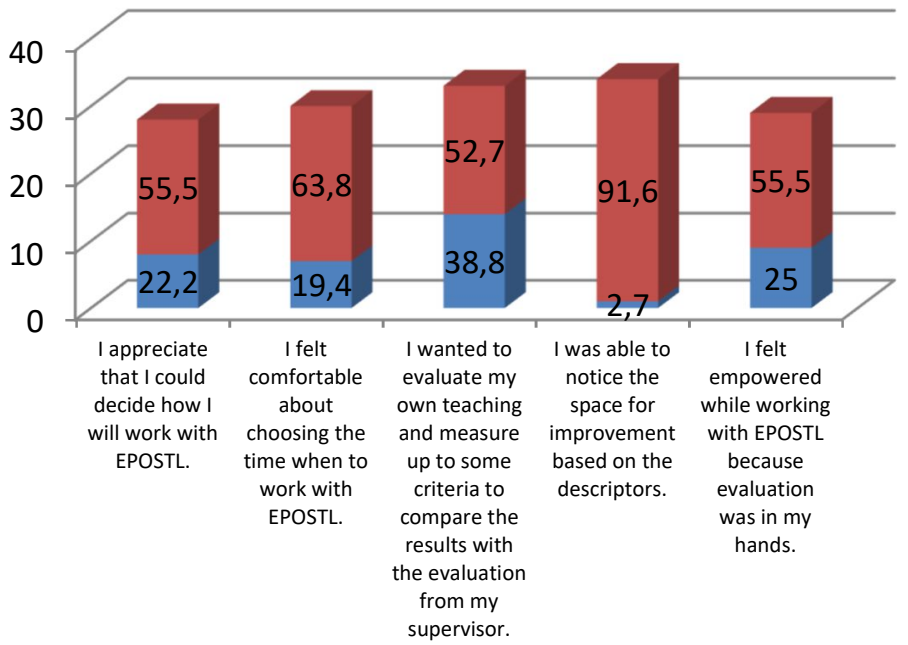

This could be caused by their lack of experience with an autonomous approach in education in general; however, it may also reflect their hesitance in taking over the control of their own development. On the other hand vast majority expressed that having clear descriptors actually helped them to identify the space for 
improvement and their strengths. It can be a positive shift from a rather superficial reflection which is commonly based on "I liked" factor that trainees tend to use after teaching a lesson.

It can also be seen from the data that even though trainees indicated very high agreement with the self-evaluation of their own performance especially with the intention to identify the space for improvement, they did not check the descriptors in advance which might indicate they did not consider possible aims or desired performance before they started to teach $(38,8 \% A / 61,1 \% D$ in "responsibility" category).

What trainees seemed to appreciate as well $(63,8 \% \mathrm{~A})$ within the autonomy category was the organisation of their own work considering especially the time when they worked with to portfolio.

Figure 3: Category 3: Development

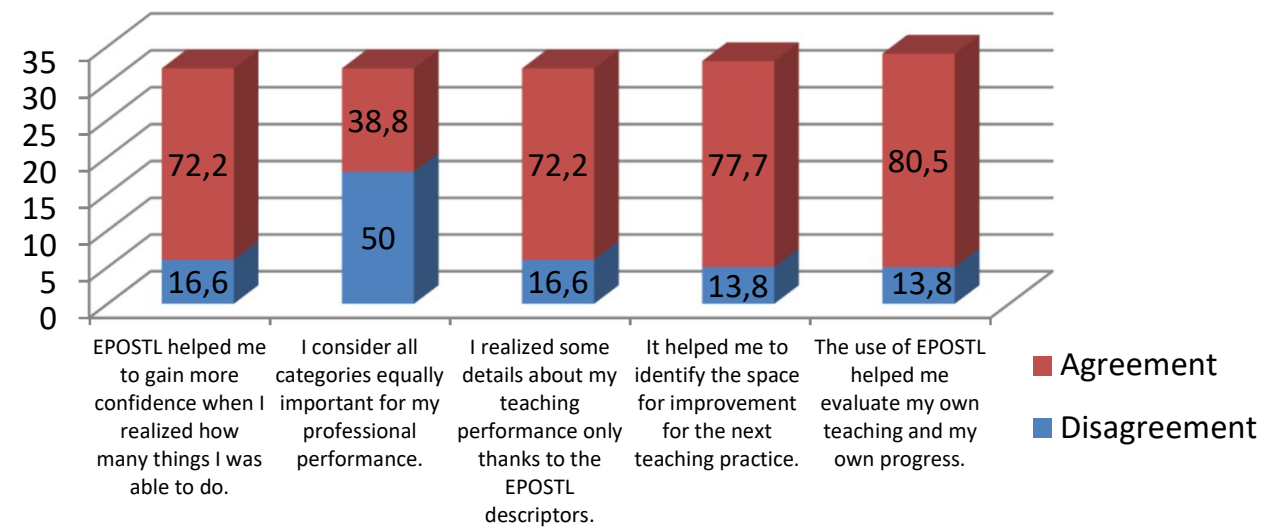

In the development category, it becomes clear that it is important for trainees to discover besides the space for improvement also the areas in which they perform on satisfactory level (EPOSTL helped me to gain more confidence when I realized how many things I was able to do. $72,2 \% \mathrm{~A})$. Even though tutors or supervising teachers try to highlight both positive aspects of their teaching and the aspects to consider (i.e. negative points) the trainees tend to focus on the negatives. From this perspective, the EPOSTL offers a tool for acknowledgement of many details which would otherwise remain unnoticed (I realized some details about my teaching performance only thanks to the EPOSTL descriptors. 72,2\%A with distribution SlA25\%, MA33,3\%, StA13,8\%). In evaluation EPOSTL seems to play an important role in building a more balanced self-perception since the teaching practice is traditionally evaluated by the supervising teachers only. Trainees, however, often feel that the evaluation of their supervising teacher is based on the 
slovakEdu, o.z.

observation of several lessons only, or there are often the cases of clash between the trainee's willingness to experiment and the supervisor's fixed routine with the expectations that the trainee will keep them. Thus, trainees sometimes feel this kind of evaluation as unfair and are happy to have some evidence of their own viewpoint that can be presented to their tutors.

Trainees also indicated that not all descriptors seemed to be equally important for them at that level of development (only 38,8\%A).

Beliefs category focused on addressing trainees' assumptions connected to their own development as teachers. Beliefs seem to be a key factor in decisionmaking process and it is important to address them overtly in a pre-service teacher training. The high level of agreement that EPOSTL will help trainees become better teachers $(83,3 \% A)$ stands in slight contrast with their views on whether the EPOSTL is an important tool for pre-service trainees $(58,3 \% A)$ which might indicate that the belief is evaluated in a higher way than the actual experience with it. The positive consequences of the concrete experience might not be so evident from the very beginning.

Figure 4: Category 4: Beliefs

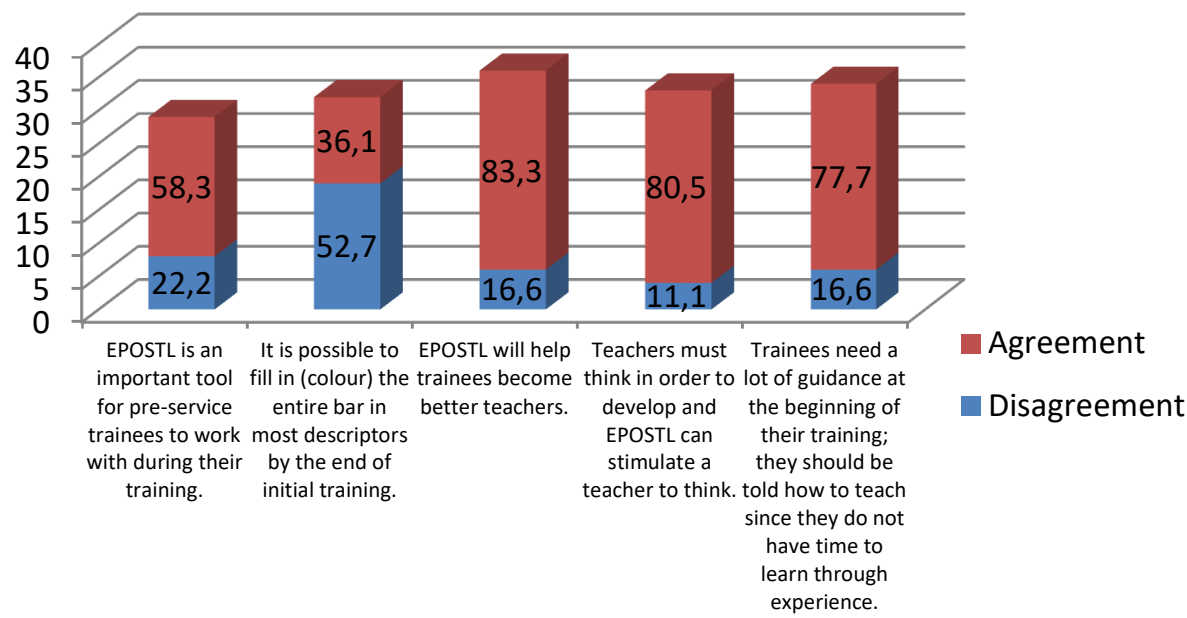

What seems to be an interesting finding is that trainees revealed their assumption about the level of guidance that trainees need at the beginning of their training; they should be told how to teach since they do not have time to learn through experience $(77,7 \% \mathrm{~A}$ with a distribution $8,3 S I A, 19,4 \% M A, 50 \% S t A)$ since it 
correlates with a low willingness of trainees to take over the control of their developmental process expressed in the category "autonomy".

The category of practicality (fig. 5) monitored mainly such aspects as clear descriptors which did not require further study, time necessary for working with EPOSTL, paper-and-pen version vs. electronic version of the portfolio, etc. In general trainees view the portfolio as a practical document and they did not object to using such a document during their teaching practice.

Fig. 5: Category 5: Practicality

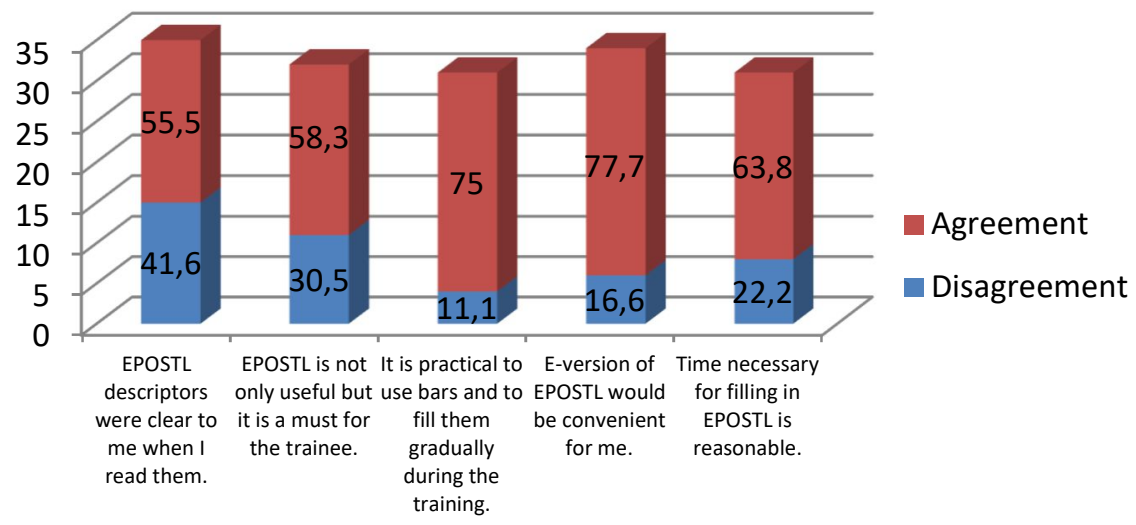

In general, attitudes of trainees towards the EPOSTL as a developmental tool for reflection in pre-service teacher training are positive and trainees do realize that portfolio helps them to break down the complexity of teacher's job into individual aspects and consider those separately. Four categories brought very similar average results for individual items (fig.6) but one category - the responsibility-related category - resulted in much lower level of agreement and demonstrates the space were trainees need more guidance.

In general, it can be concluded that the detailed concept of EPOSTL was found in general corresponding with the need of trainees to be instructed, to be guided and to be told what to look at. In this respect EPOSTL can be viewed as a beneficial tool in their own development as teachers. 
Figure 6: Average - individual items and categories

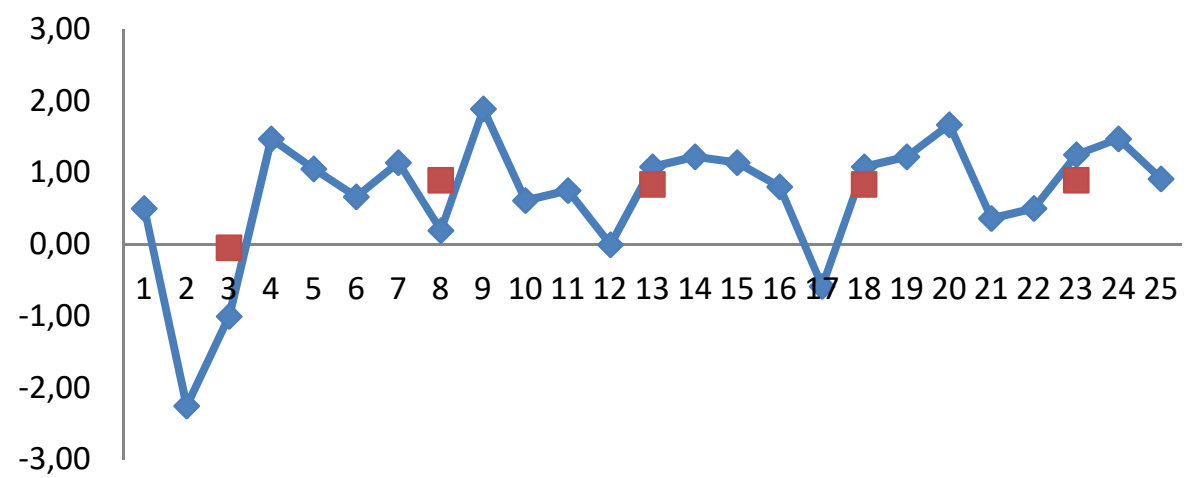

\section{Conclusion}

Pre-service teacher training offers rather limited space for trainees to develop in all aspects of teaching skills. On contrary tutors usually find it problematic to choose which areas deserve more attention and to identify what approach could create more space for their development. Reflective part of this developmental process seems to be inseparable since it provides the opportunity for conceptualization of a concrete experience and generalization of specific contexts. The use of portfolio (in this case EPOSTL) for such cases will provide a solid starting point; however, it cannot be taken for granted that trainees will understand how they should use this tool. Trainees need a profound preparation before they start using it. The case study presented in this article points to remarkable lapses of trainees' anticipations if such preparation is missing.

At the same time, it seems unrealistic to expect that trainees will manage to focus their attention on all descriptors during a short phase. For a deep reflection trainees need to be guided or talked through the process to see what is expected from them, to reach the full understanding of the benefits of this process. Dialogical reflection (Chick, 2015, Walsh, Mann, 2015) or guided reflection can prepare them for the process they need to undergo in order to avoid superficial conclusions and tendency to tick the task as completed without the minimum effort.

Last but not least it is important to organize the work with EPOSTL in such a way that it provides space for clarification, proofs and evidence of a declared skilllevel, and justification. Gün (op.cit., p.127) argues for the difference between "reflection" and "critical reflection" where the former as a superficial process ends by commenting on general feelings or acts in a descriptive way and the latter involves "why" question-and-answer process since only a genuine search for such answers can generate a deeper understanding followed by learning. 
Trainees in pre-service training operate mainly on the base of prior experience as a learner and their belief system guides them during their decision-making process, during the act of teaching. They do not have a wide repertoire of experience-based strategies to use so they apply "the known, the experienced" even though they probably did not approve them as learners themselves. At this moment, however, they represent the solution in times of trouble. For this reason, the reflection cannot be avoided in pre-service training since this is the only way how beliefs can be disclosed on the base of argumentation and justification of the teaching acts. Trainees, therefore, need a variety of reflection tools to guide their cognition and to help them perceive and understand their own teaching from multiple angles. EPOSTL might serve as a useful tool for the initial teaching practice; however, further assistance is necessary to achieve desirable outcomes.

Acknowledgements: This article is a partial outcome of the research project KEGA 065PU-4/2016

\section{References}

Belásová, L. \& Bernátová, R. (2007). Portfólio v profesijnej príprave učitel’ov elementaristov. In Píšová, M. ed. (2007). Portfolio v profesní př́pravě učitele (pp. 53-56). Pardubice: Univerzita Pardubice.

Bullock, D. (2011). Learner self-assessment: an investigation into teachers' beliefs. ELT Journal, 65(2), 114-125, doi:10.1093/elt/ccq041

Chick, M. (2015). The education of language teachers: instruction or conversation? ELT Journal, 69(3) July 2015, 297-307, Oxford University Press, doi:10.1093/elt/ccv011

Cimermanová, I. (2015). Digital Portfolio in Building Teaching Efficacy of PreService Teachers. Journal of Language and Cultural Education, 3(1), 112-129.

Dewey, J. (1933). How We Think: A Restatement of the relation of Reflective Thinking to the Educative Process. Chicago: Henry Regnery Comp.

Eröz-Tuğa, B. (2013). Reflective feedback sessions using video recordings. ELT Journal, 67(2); doi:10.1093/elt/ccs081

Gough, D. (2007). Weight of Evidence: A Framework for the Appraisal of the Quality and Relevance of Evidence. In Furlong,J., Oancea,A. (eds.) Applied and Practice-based Reasearch. Special Edition of Research Papers in Education, 22, (2), 213-228.

Gün, B. (2011). Quality self-reflection through reflection training. ELT Journal, 65(2), 126-135, doi:10.1093/elt/ccq040

Lam,R. \& Lee,I. (2010). Balancing the dual functions of portfolio assessment. ELT Journal, 64(1), 54-64, doi:10.1093/elt/ccp024

MacBeath, J., Schratz,M., Meuret, D., \& Jacobsen, L. (2000). Self-evaluation in European Schools: A Story of Change. London: RoutledgeFalmer, 
Marzano, R. et al (2012). Becoming a Reflective Teacher. Marzano Research.

Newby, J. et al. (2007) European Portfolio for Student Teachers of Languages: A reflection tool for language teacher education. Available at: http://www.ecml.at/epostl

Píšová, M. ed. (2007). Portfolio v profesní přípravě učitele. Pardubice: Univerzita Pardubice.

Pollard, A. et al. (2008). Reflective Practice: Evidence-informed Professional Practice, London: Continuum,

Richards, J. C. \& Lockhart, C. (1994). Reflective Teaching in Second Language Classroom. Cambridge University Press,

Spilková, V. (2007). Význam portfolia pro profesní rozvoj studentů učitelství. In Píšová, M. ed. (2007). Portfolio v profesní prípravě učitele (pp. 7-20). Pardubice: Univerzita Pardubice.

Straková, Z. (2010). European Portfolio for Student Teachers of Languages and Its Benefits for Pre-service Teacher Training. English Matters (pp. 79-83). Prešov: Prešovská univerzita v Prešove.

Straková, Z. (2015). The perception of readiness for teaching profession: a case of pre-service trainees. Journal of language and cultural education. 3(1), 53-67.

Walsh, S., Mann, S. (2015). Doing reflective practice: a data-led way forward. ELT Journal, 69(4), 351-362, doi: 10.1093/elt/ccv018

Woods,D. (1996). Teacher Cognition in Language Teaching. Cambridge University Press.

\section{Contact}

assoc.prof. Zuzana Straková, PhD.

Institute of British and American Studies

Faculty of Arts, Univeristy of Presov

17. novembra 1

08001 Presov

Slovakia

zuzana.strakova@unipo.sk 


\section{Appendix: EPOSTL Questionnaire for Trainees}

\begin{tabular}{|c|c|c|c|c|c|c|c|c|}
\hline & $\begin{array}{l}\text { 7: Strongly Agree (most true); } \\
\text { 6: Moderately Agree; } \\
\text { 5: Slightly Agree; } \\
\text { 4: Neutral; } \\
\text { 3: Slightly Disagree; } \\
\text { 2: Moderately Disagree; } \\
\text { 1: Strongly Disagree (least true) }\end{array}$ & 1 & 2 & 3 & 4 & 5 & 6 & 7 \\
\hline 1 & $\begin{array}{l}\text { I was able to fill in all bars for each } \\
\text { descriptor. }\end{array}$ & & & & & & & \\
\hline 2 & $\begin{array}{l}\text { I informed my supervising teachers } \\
\text { about EPOSTL. }\end{array}$ & & & & & & & \\
\hline 3 & $\begin{array}{l}\text { I checked the descriptors before the } \\
\text { teaching practice started. }\end{array}$ & & & & & & & \\
\hline 4 & $\begin{array}{l}\text { I am interested in what results my } \\
\text { colleagues have reached while teaching. }\end{array}$ & & & & & & & \\
\hline 5 & $\begin{array}{l}\text { While working with EPOSTL I felt more } \\
\text { responsibility for my own progress. }\end{array}$ & & & & & & & \\
\hline 6 & $\begin{array}{l}\text { I appreciate that I could decide how } \\
\text { I will work with EPOSTL. }\end{array}$ & & & & & & & \\
\hline 7 & $\begin{array}{l}\text { I felt comfortable about choosing the } \\
\text { time when to work with EPOSTL. }\end{array}$ & & & & & & & \\
\hline 8 & $\begin{array}{l}\text { I wanted to evaluate my own teaching } \\
\text { and measure up to some criteria to } \\
\text { compare the results with the evaluation } \\
\text { from my supervisor. }\end{array}$ & & & & & & & \\
\hline 9 & $\begin{array}{l}\text { I was able to notice the space for } \\
\text { improvement based on the descriptors. }\end{array}$ & & & & & & & \\
\hline 10 & $\begin{array}{l}\text { I felt empowered while working with } \\
\text { EPOSTL because evaluation was in my } \\
\text { hands. }\end{array}$ & & & & & & & \\
\hline 11 & $\begin{array}{l}\text { EPOSTL helped me to gain more } \\
\text { confidence when I realized how many } \\
\text { things I was able to do. }\end{array}$ & & & & & & & \\
\hline 12 & $\begin{array}{l}\text { I consider all categories equally } \\
\text { important for my professional } \\
\text { performance. }\end{array}$ & & & & & & & \\
\hline
\end{tabular}




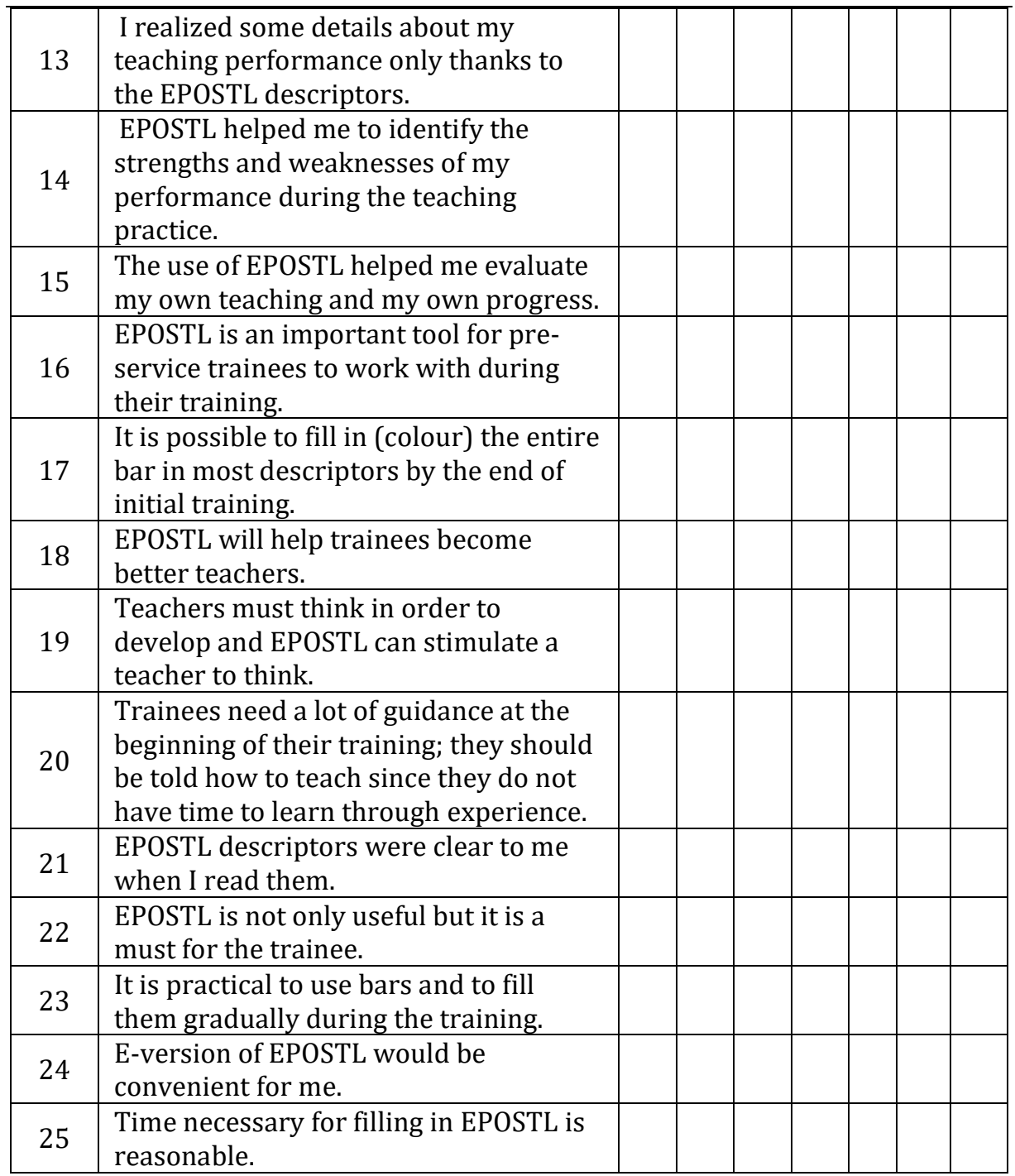

